University of Nebraska - Lincoln

DigitalCommons@University of Nebraska - Lincoln

2016

Hydrologic response and recovery to prescribed fire and vegetation removal in a small rangeland catchment

Gerald N. Flerchinger

USDA-ARS, gerald.flerchinger@ars.usda.gov

M.S. Seyfried

USDA-ARS, mark.seyfried@ars.usda.gov

Stuart P. Hardegree

USDA-ARS, stuart.hardegree@ars.usda.gov

Follow this and additional works at: https://digitalcommons.unl.edu/usdaarsfacpub

Flerchinger, Gerald N.; Seyfried, M.S.; and Hardegree, Stuart P., "Hydrologic response and recovery to prescribed fire and vegetation removal in a small rangeland catchment" (2016). Publications from USDAARS / UNL Faculty. 1806.

https://digitalcommons.unl.edu/usdaarsfacpub/1806

This Article is brought to you for free and open access by the U.S. Department of Agriculture: Agricultural Research Service, Lincoln, Nebraska at DigitalCommons@University of Nebraska - Lincoln. It has been accepted for inclusion in Publications from USDA-ARS / UNL Faculty by an authorized administrator of DigitalCommons@University of Nebraska - Lincoln. 


\title{
Hydrologic response and recovery to prescribed fire and vegetation removal in a small rangeland catchment
}

\author{
G. N. Flerchinger,* M. S. Seyfried and S. P. Hardegree \\ USDA Agricultural Research Service, Northwest Watershed Research Center, Boise, ID, USA
}

\begin{abstract}
Prescribed fire can be used to return wild lands to their natural fire cycle, control invasive weeds, and reduce fuel loads, but there are gaps in the understanding of post-disturbance responses of vegetation and hydrology. The impact of a prescribed fire and subsequent aspen cutting on evapotranspiration (ET) and streamflow was assessed for the Upper Sheep Creek catchment, a 26-ha headwater catchment dominated by low sagebrush, mountain big sagebrush, and aspen within the Reynolds Creek Experimental Watershed. The 2007 prescribed fire consumed 100\% of the mountain big sagebrush and approximately $21 \%$ of the low sagebrush. The aspen, which were mostly untouched by the fire, were cut in the fall of 2008. Post-disturbance ET and vegetation recovery were related to the loss of rooting depth. ET recovered within 2 years on the low sagebrush area with limited rooting depth, while that on the deeper-rooted mountain big sagebrush area took 4 years to recover. ET from the aspen trees, which can sprout from existing roots, recovered within 2 years. The influence of vegetation disturbance on streamflow was assessed using both empirical time trend analysis and process-based modelling. Although both approaches suggested approximately a $20 \%$ increase in streamflow during the 6 years post-disturbance, results from the empirical time trend analysis were marginally significant $(p=0.055)$, while those from the process-based modelling were not statistically significant. Marginal streamflow response can be attributed to rapid post-disturbance recovery of the aspen where most of the streamflow originates. Published 2016. This article is a U.S. Government work and is in the public domain in the USA
\end{abstract}

KEY WORDS evapotranspiration; rangeland; root depth; streamflow; water balance

Received 14 January 2016; Revised 3 May 2016; Accepted 8 May 2016

\section{INTRODUCTION}

Wildland fire played a fundamental role in the development and maintenance of shrub-steppe plant communities in the Intermountain western USA and similar ecosystems worldwide. Prescribed fire is often used to return wildlands to their natural fire cycle, control invasive weeds, improve habitat, and reduce fuel loads (Ryan et al., 2013). Despite the evidence that fire is critical for maintaining the structure and function of shrub-steppe ecosystems, fire has not been restored as a fundamental process on much of the Intermountain West, resulting in widespread juniper encroachment and degradation of these ecosystems (Miller and Rose, 1999; Miller et al., 2005; Twidwell et al., 2013).

Numerous catchment studies have reported the hydrologic effects of vegetation change (Bosch and Hewlett, 1982; Brooks and Vivoni, 2008) with many giving conflicting results. Most studies in forested catchments report an increase in streamflow following removal of trees (Bosch and Hewlett, 1982; Stednick, 1996; Brown et al., 2005; Huang et al., 2006).

*Correspondence to: Gerald N. Flerchinger, USDA Agricultural Research Service, Northwest Watershed Research Center, 800 Park Boulevard, Suite 105, Boise, ID 83712, USA. E-mail gerald.flerchinger@ars.usda.gov
However, a few studies, such as Guardiola-Claramonte et al. (2011) and Biederman et al. (2015), have shown decreased streamflow following tree die-off. Reasons given for this counter-intuitive observation is increase in understory cover and an increase in solar radiation reaching the understory resulting in increased sublimation and evapotranspiration (ET) (Biederman et al., 2014a, 2014b; Harpold et al., 2014).

Studies on juniper and shrubs have tended to focus on woody encroachment into grasslands. Although Wilcox et al. (2005, 2008) showed little to no increase in streamflow or baseflow after large increases in woody plants (mesquite and juniper) in areas with 450 to $710 \mathrm{~mm}$ of precipitation, Huang et al. (2006) found that streamflow increased $46 \mathrm{~mm}$ following juniper removal in a $900-\mathrm{mm}$ precipitation zone. Wilcox (2002) pointed out that while numerous factors affect catchment response to shrub control, precipitation is the dominate factor, with little potential for increased streamflow from shrub control where annual precipitation is less than $500 \mathrm{~mm}$. Despite the many studies in forested and juniper sites, there are very few studies of fire effects on catchmentscale water balance and streamflow in sagebrush-steppe ecosystems where juniper encroachment is increasing.

Studies on the effects of vegetation change on catchment hydrology often rely on a paired watershed approach 
(Brown et al., 2005), which can prove problematic because it is often difficult to find watersheds that are truly 'paired' and climate variability can influence the apparent response (Zhang et al., 2012; Biederman et al., 2015; Burt et al., 2015). Additionally, results are not always extendible beyond the area of interest because streamflow generating processes within the watershed are not directly addressed. An alternative approach is time trend analysis (Bosch and Hewlett, 1982; Huang et al., 2006; Zhao et al., 2010; Guardiola-Claramonte et al., 2011; Biederman et al., 2015), in which an empirical pre-disturbance model is developed by correlating hydrological processes with meteorological observations and post-disturbance observations are compared with predictions. If the empirical models fail to predict post-disturbance observations, one may assume there was a change in watershed relations, but little can be said about specific processes. An extension of the time trend analysis is to test and verify that a processbased model can simulate processes of interest, i.e. ET, soil water loss, streamflow, etc., for an extended period before vegetation change and then compare post-treatment observations with simulation results. The advantages of using a process-based model are that streamflow generating processes and partial area contributions can be addressed, useful information can be obtained even in arid areas when no run-off is observed, and sensitivity testing can extend knowledge gained beyond field observations.

The USDA Agricultural Research Service, Northwest Watershed Research Center (NWRC) conducted a series of studies and created a 24-year water balance for the Upper Sheep Creek catchment located in the Reynolds Creek Experimental Watershed (Chauvin et al., 2011). Upper Sheep is similar to many mid-elevation to high-elevation watersheds of the semi-arid Intermountain West sagebrush steppe having ephemeral streamflow and dominated by snowmelt, ET, and relatively shallow subsurface water flow downslope to the stream. Taking advantage of the unique long-term data record and knowledge base developed for this catchment, NWRC conducted a prescribed fire within the Upper Sheep Creek catchment in September 2007 to investigate the effects of prescribed fire and vegetation removal on hydrologic response. Although the site was only in the initial stages of juniper encroachment and a prescribed fire may have been premature from a management standpoint, it afforded the opportunity to evaluate the impact of vegetation changes in sagebrush-steppe ecosystems. Thus, the objective of this paper was to assess the response and recovery of vegetation, rooting depth, ET, and streamflow to vegetation disturbance using a combination of observations, processbased model application, and time trend analysis. We hypothesized that, for a semi-arid catchment dominated by subsurface flow processes where precipitation is out of phase with transpiration demand and vegetation must rely on stored soil moisture through the growing season, ET would decrease and streamflow would increase in the years immediately following disturbance (Huxman et al., 2005; Seyfried and Wilcox, 2006). Vegetation disturbance would likely cause reduced ET and thereby would reduce soil moisture deficit and increase percolation through the soil profile and subsurface flow to the stream (Flerchinger and Clark, 2003; Chauvin et al., 2011). Overland flow and sediment production resulting from post-fire hydrophobicity and changes in post-disturbance snow drifting were not apparent in the watershed and are therefore not addressed.

\section{BACKGROUND}

Detailed studies of the Upper Sheep Creek Watershed were conducted by the USDA-ARS NWRC from 1984 through 1994. Numerous investigations were conducted to define the geology of the watershed (Winkelmaier, 1987; Mock, 1988; and Stevens, 1991) and to better understand the processes controlling hydrologic response (Cooley, 1988; Flerchinger et al., 1992; Flerchinger et al., 1993; Deng et al., 1994; Flerchinger et al., 1994; Unnikrishna et al., 1995; Flerchinger et al., 1996; Luce et al., 1998). Chauvin et al. (2011) conducted a 24-year (1984 through 2007) water balance of the watershed that effectively characterized pre-fire hydrologic response. To account for spatial heterogeneity in hydrologic processes, the watershed was broken into three zones based on similarity in soils, vegetation, and snow accumulation (low sagebrush, mountain big sagebrush, and aspen), and a partial water budget was computed for each zone. Two approaches were taken to correlate streamflow to watershed processes. Area-weighted winter-spring precipitation and antecedent moisture conditions accounted for 83\% of streamflow variability. Additionally, Chauvin et al. (2011) demonstrated that area-weighted percolation of water beyond the root zone simulated by the Simultaneous Heat and Water (SHAW) model correlated well with streamflow $\left(r^{2}=0 \cdot 85\right)$. Subsequently, Flerchinger and Seyfried (2014) quantified ET for two vegetation types within the Upper Sheep Creek Catchment by comparing estimates from eddy covariance (EC), measured soil moisture profiles, and model simulations over a 6-years study period spanning the vegetation disturbance. They demonstrated that ET could be simulated accurately before and after vegetation treatments.

\section{METHODS}

\section{Study site}

The site is the Upper Sheep Creek study area, a semi-arid rangeland catchment located within the Reynolds Creek Experimental Watershed in the Owyhee Mountains of southwestern Idaho, USA (Marks, 2001; Slaughter et al., 
2001). It is a $0 \cdot 26-\mathrm{km}^{2}$ headwater catchment with an elevation range of $1840-2036 \mathrm{~m}$. A topographical map and instrument locations for the catchment are presented in Figure 1; locations within the watershed are referenced by the overlying $30-\mathrm{m}$ grid. Average annual precipitation measured at D03 from 1984 through 2007 was $426 \mathrm{~mm}$ (Chauvin et al., 2011) and that measured at $\mathrm{J} 10$ was $572 \mathrm{~mm}$, with approximately $60 \%$ occurring as snow. The site is underlain by basalt. Intermittent streamflow is generated almost entirely by subsurface flow of snowmelt, producing an average annual yield of approximately $44 \mathrm{~mm}$.

Three landscape units within the catchment were identified based on similarity in vegetation, snow accumulation, and soils (inset of Figure 1; Flerchinger and Cooley, 2000; Chauvin et al., 2011). The southwest-facing slopes are sparsely vegetated with low sagebrush (Artemisia arbuscula) and some grasses. These exposed areas have little or no snow cover in the winter. Soils here are generally high in rock content $(>50 \%)$ and shallow $(\sim 30$ to $60 \mathrm{~cm})$ and contain relatively high clay content $(\sim 25 \%)$ argillic horizons and thin $(<10 \mathrm{~cm})$ silt loam surface horizons. Mountain big sagebrush (Artemisia tridentata vaseyana), snowberry (Symphoricarpos spp.), and grasses/forbs covered the lower portions of the northeastfacing slopes prior to the prescribed fire. These areas typically accumulate about a metre of snow over the winter, and soils are deep loess-derived silt loam having low rock content. The upper portions of the northeastfacing slopes are predominantly vegetated by aspen (Populus tremuloides) and willow (Salix spp.) thickets.
Large snow drifts (varying in depth from $1 \mathrm{~m}$ to typically $5 \mathrm{~m}$ ) form annually in these areas. Soils here are virtually rock free and are very deep $(>200 \mathrm{~cm})$ loess-derived silt loam. These units are referred to as the low sagebrush, mountain big sagebrush, and aspen zones (inset of Figure 1) and comprise $58.9 \%, 26.6 \%$, and $14.5 \%$ of the catchment, respectively. Wester juniper (Juniperus occidentalis) was observed to encroach into all three vegetation zones over the 20 years of observation within the catchment, with a few scattered trees growing to approximately $3 \mathrm{~m}$ (less than 10 within each zone) prior to treatment.

\section{Vegetation disturbance}

In order to maximize the hydrologic response and to observe vegetation recovery, the prescription for the 2007 fire within the Upper Sheep study area called for at least $50-75 \%$ of the watershed to be burned with almost total consumption of mountain big sagebrush and aspen. The boundary of the resulting prescribed fire shown in Figure 2 shows $100 \%$ consumption of the mountain big sagebrush zone and approximately $21 \%$ of the low sagebrush zone; only a few trees on the edge of the aspen thicket were scorched. Trees within the aspen thicket were therefore cut near ground level in September 2008 and left.

\section{Field data}

Leaf area index (LAI) and vegetation biomass sampling have been conducted annually at peak standing biomass

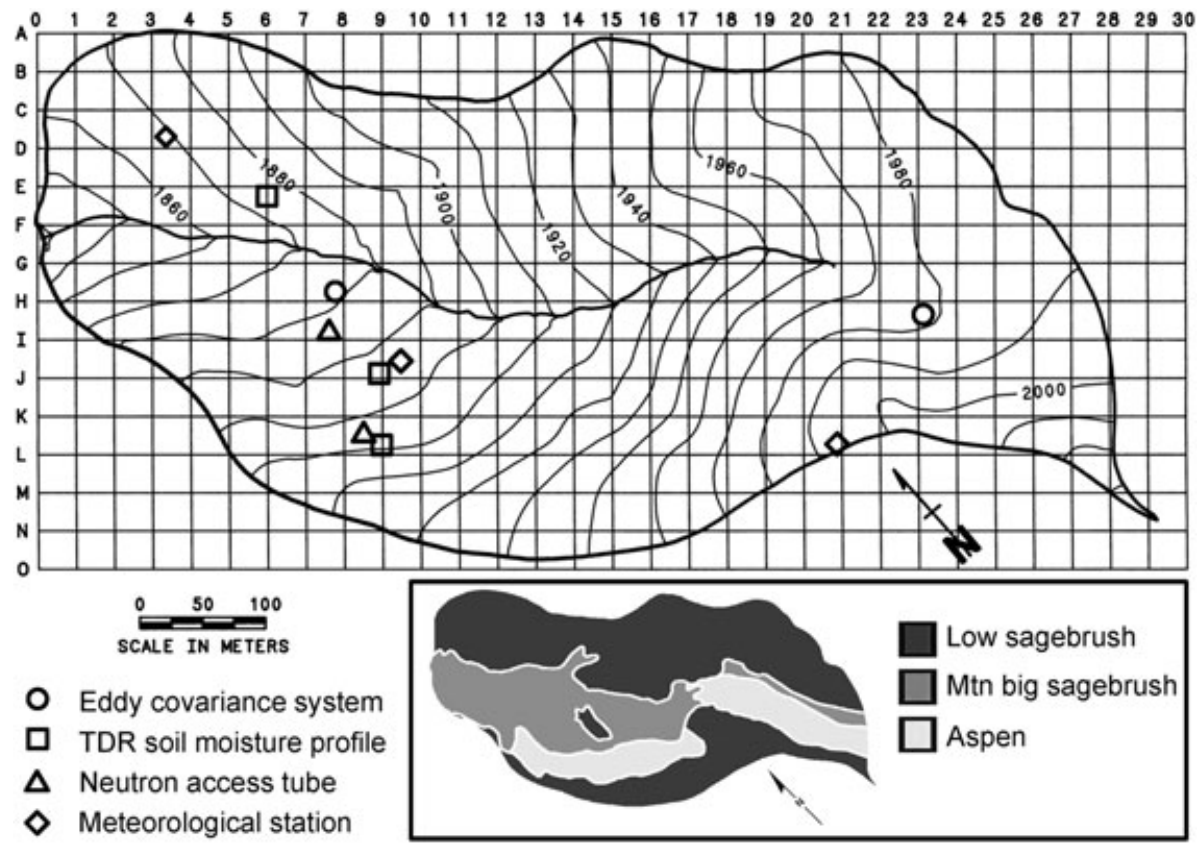

Figure 1. Upper Sheep Creek catchment orientation, elevation range, and instrumentation. Instruments locations are referenced by the overlying 30-m grid. The three landscape zones based on similarity in vegetation, snow accumulation, and soils are depicted in the inset. 


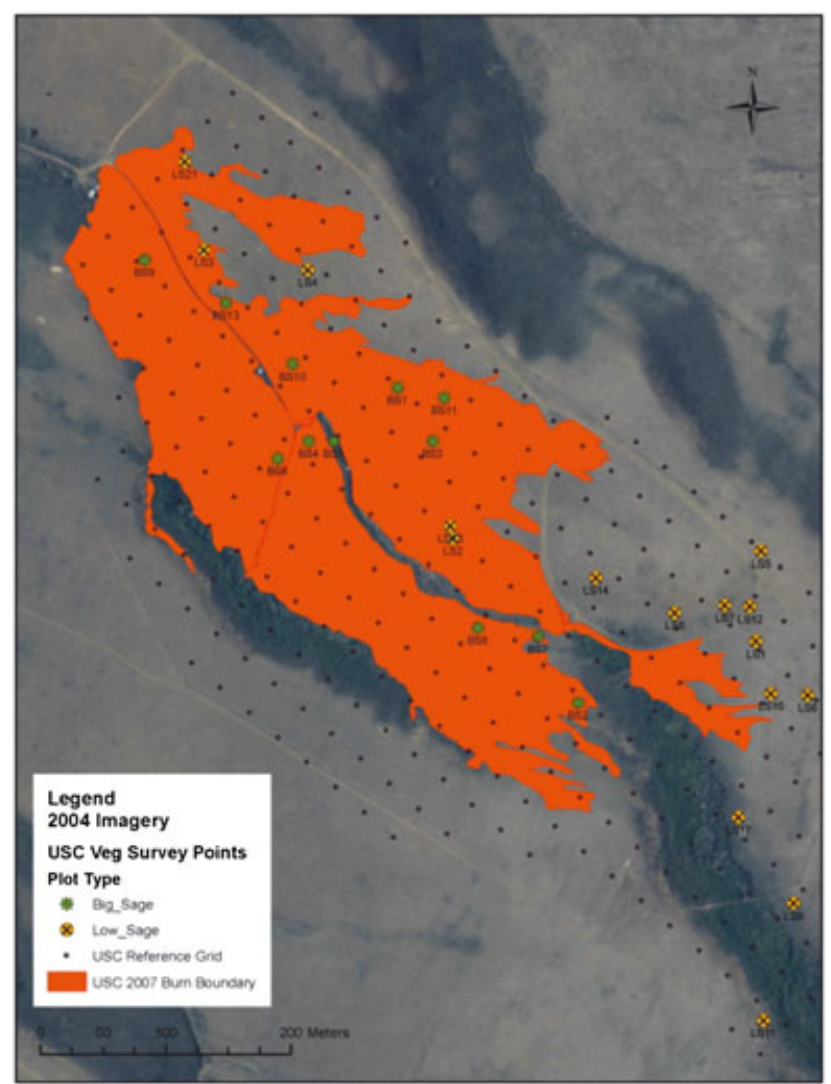

Figure 2. Burn boundary and locations of point-frame LAI measurement plots within the Upper Sheep Creek (USC) catchment.

since 2006 in the low sagebrush and mountain big sagebrush zones. LAI was measured using the pointintercept method (also referred to as point quadrat method; Clark and Seyfried, 2001) on 16 randomly selected $1-\mathrm{m}^{2}$ plots in the low sagebrush zone and 12 plots in the mountain big sagebrush zone (Figure 2). LAI of the aspen trees was estimated by taking the difference between measurements taken beneath the canopy at peak growth and after leaf-fall using a light interception instrument (LAI-2000, Li-Cor, Inc., Lincoln, Nebraska). LAI of the grass understory beneath the aspen was measured separately using the same light interception instrument.

Air temperature, precipitation, relative humidity, solar radiation, and wind speed measurements collected on the southwest-facing low sagebrush site and the northeastfacing mountain big sagebrush site (Figure 1) were used for SHAW model input. Hourly soil water content profiles were measured using a TDR 100 system (Campbell Scientific, Logan, Utah). Three-prong TDR rods $(30.5 \mathrm{~cm}$ long, $0.5 \mathrm{~cm}$ diameter) were installed horizontally in a pit face at depths of $10,30,40$, and $50 \mathrm{~cm}$ in the low sagebrush zone at grid location F6; 10, 30, 60, 90, and $120 \mathrm{~cm}$ in the mountain big sagebrush zone at grid location J9 (Figure 1); and $10,30,60,90,120,150$, and $180 \mathrm{~cm}$ in the aspen at L9. Six neutron access tubes were installed to varying depths in each of the mountain big sagebrush and aspen zones. The deepest tubes in the mountain big sagebrush and aspen, installed to approximately 225- and 270-cm depths and located at grid locations I8 and K9 (Figure 1), respectively, were used for analyses. Neutron tubes were read bi-weekly during the growing season (typically May through October) starting in July 2005. Readings were taken at 15- or 30-cm increments (Seyfried et al., 2001).

Evapotranspiration estimates from TDR based on a water balance of the soil column as computed by Flerchinger and Seyfried (2014) were used herein. ET for the TDR profiles was estimated directly from the change in storage within the profile $(\Delta \mathrm{S})$, assuming ET was zero on days with an increase in soil water storage, typically indicating precipitation for that day. This assumed that deep percolation of water beyond the measurement depth, net lateral flow of water into the soil profile, and net runoff/run-on from the soil surface are negligible. Thus, ET analyses were conducted only during the growing season after snowmelt when lateral flow and deep percolation beyond the root zone were minimal (Flerchinger and Seyfried, 2014); overland flow is seldom if ever observed in the catchment. Additionally, this approach assumes that the effective rooting depth did not extend beyond the measured profile. ET estimates commenced on calendar day 100 (April 10) for the low sagebrush zone and day 121 (May 1) for the mountain big sagebrush zone. For most years, ET estimates began on day 165 for the aspen zone but were delayed until day 175 for 2008 and day 180 for 2011 owing to late snowmelt and percolation occurring beyond the root zone of the aspen (Flerchinger and Seyfried, 2014). ET estimates were carried through day 330 (November 26) for the sagebrush zones. Flerchinger and Seyfried (2014) noted that for many of the years, ET measured by EC increased slightly in the early fall after day 290, while model simulations and TDR-measured soil water loss tapered off. Therefore, analysis of the aspen zone herein was limited to the period before leaf drop, taken as October 1 (day 274). Cumulative weekly and seasonal ET for the TDR profiles were taken as the sum of the daily ET values.

Open path EC systems as described by Flerchinger and Seyfried (2014) were installed in September 2004 above the aspen near grid location I23 and in August 2005 above the mountain big sagebrush (H8); these systems were subsequently run nearly continuously to monitor the surface energy balance. Sites were selected to optimize fetch in the predominant wind direction, which blows roughly parallel to the catchment drainage at approximately $330^{\circ}$ from north. Maximum fetch for the aspen was approximately $150 \mathrm{~m}$, and that for the sagebrush was over $200 \mathrm{~m}$. Fetch for westerly winds was $65 \mathrm{~m}$ for the aspen, limited by the width of the aspen thicket, and $80 \mathrm{~m}$ for the sagebrush, limited by the distance to an aspen thicket. 
Periods with a wind direction having improper fetch (i.e. coming directly over low sagebrush to the north and east) were flagged for filling of the latent heat flux data. Postprocessing of the 30-min EC data included sonic temperature correction (Schotanus et al., 1983), density correction (Webb et al., 1980), and coordinate rotation (Kaimal and Finnigan, 1994). Gaps in the EC data, whether due to improper fetch or instrumentation problems, were filled using linear regression by correlating observations of the surrounding 14-day period to observed solar radiation. Latent and sensible heat fluxes were adjusted to force closure of the energy balance while maintaining the Bowen ratio, i.e. ratio of sensible to latent heat flux (Twine et al., 2000). This was problematic when the Bowen ratio approached $-1 \cdot 0$. Therefore, whenever the magnitude of $H+L E$ was less than the error in the energy balance, $H$ and $L E$ were adjusted equally to compensate for the error and to force energy balance closure.

\section{Model simulations}

The SHAW model was applied to demonstrate treatment effects on rooting depth, ET, and streamflow by simulating pre-treatment and post-treatment vegetation conditions. The SHAW model has been tested and applied extensively over a range of vegetation types in semi-arid and arid environments, including previous studies within the Upper Sheep catchment (Flerchinger et al., 1996, 1998, 2012; Chauvin et al., 2011; Flerchinger and Seyfried, 2014). Version 3.0b of the model was used for this study, with modifications for radiation transmission and scattering within the canopy (Flerchinger and Yu, 2007; Flerchinger et al., 2009b), incoming long-wave radiation (Flerchinger et al., 2009a), and within-canopy turbulent transfer algorithms with correction for atmospheric stability (Flerchinger et al., 2012). The SHAW model simulates a vertical, onedimensional system composed of a vegetation canopy, snow cover (if present), plant residue, and soil profile. The surface energy balance, ET, and fluxes are simulated within a multi-species plant canopy using detailed physics of heat and water transfer through the soil-plant-atmosphere continuum, making it ideal for use in this study (e.g. Flerchinger and Cooley, 2000 and Chauvin et al., 2011). A layered system is established though the model domain, with each layer represented by a node. Plant transpiration is computed by iteratively solving the following: the leaf energy balance within each layer of the multi-layer canopy, and water flux from the soil layers, through the roots, leaves, and stomatal openings to atmospheric humidity within the canopy. Plant and stomatal resistance parameters are defined for a given plant, and temporal variability in LAI, root depth, and plant height are input to the model.

Sensitivity analyses were conducted to test previous rooting depth assumptions for the low sagebrush zone made by Chauvin et al. (2011) and for post-fire rooting depth of the mountain big sagebrush zone made by Flerchinger and Seyfried (2014). The model was then applied and compared with pre-treatment years to demonstrate simulation accuracy of pre-treatment conditions. Simulated pre-treatment weekly ET was compared with weekly ET estimates from EC observations and TDR-measured soil water loss using twotailed paired $t$-tests, thereby testing whether residuals between simulated and measured weekly ET were significantly different from zero. Post-treatment years were then simulated using average pre-treatment vegetation and actual post-treatment conditions, i.e. LAI and root depth; simulation results were compared with post-treatment observations of weekly ET and annual streamflow. Because the assumption is that post-treatment ET will decrease compared with pre-treatment conditions, single-tailed paired $t$ tests were used for comparing pre-treatment vegetation simulations with the post-treatment observations; thus the single-tailed $t$-tests examined whether the residuals between weekly measured ET and that simulated using pre-treatment conditions were significantly greater than zero. Differences were deemed not significant $(p>0 \cdot 10)$, marginally significant $(p<0 \cdot 10)$, significant $(p<0 \cdot 05)$, or highly significant $(p<0 \cdot 01)$.

The model was initialized each year with measured soil temperature and water profiles and used to evaluate the impact of vegetation disturbance on ET. Simulations for the aspen site were initiated shortly after snow ablation (23 May for 2004, 2005, and 2007 and 10 June for the remaining years) and continued through November as ET diminished and the seasonal snow pack developed. Simulations for the low and mountain big sagebrush sites were initiated on 10 April (day 100) and on 1 May (day 120), respectively, and also continued through November of each year. Vegetation parameters for aspen, sagebrush, and grasses/forbs used in the model were taken from previous studies in the area (Flerchinger et al., 1996; Flerchinger and Cooley, 2000; and Chauvin et al., 2011). Temporal variation in LAI was input to the model based on LAI measurements taken at peak standing biomass (Figure 3). Aspen leaves, grasses, and forbs were assumed to initiate growth after complete snowmelt at their respective sites; maximum LAI was assumed to occur in mid-June for the low and mountain big sagebrush site and 1 month after snow ablation at the aspen site (typically late June) based on site observations and previous studies (Flerchinger and Cooley, 2000; and Chauvin et al., 2011). Burned and unburned plots existed post-fire for the low sagebrush zone, and actual LAI measurements were used each year for the respective plots. However, undisturbed plots did not exist post-disturbance for the mountain big sagebrush and aspen zones, so simulations were run using average pre-disturbance LAI for both pre-disturbance and post-disturbance years along with simulations using 


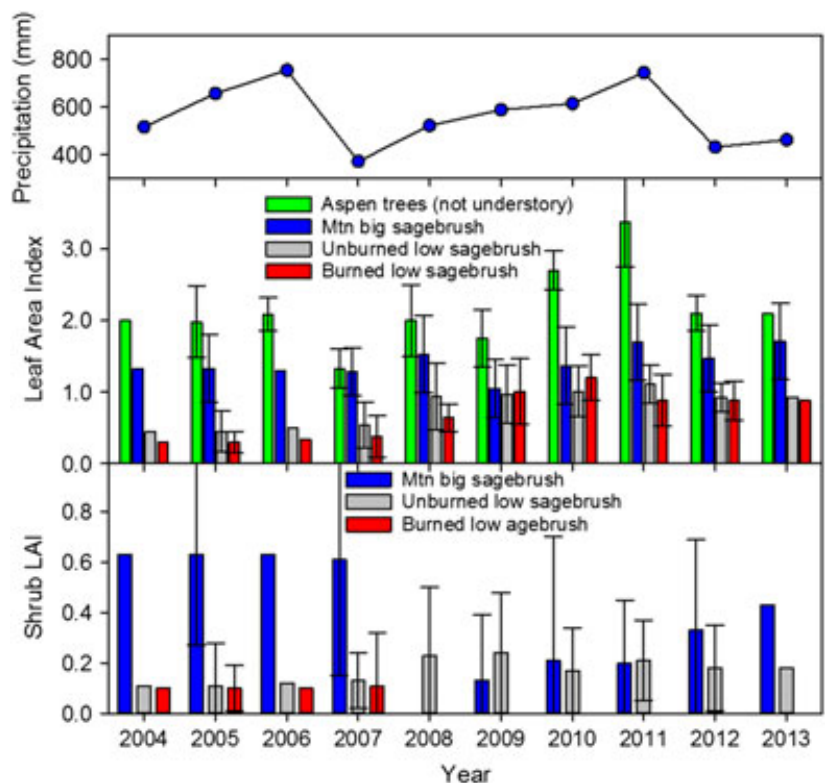

Figure 3. Water-year precipitation (defined as October through September) measured at J10 and leaf area index (LAI) for the study sites. Error bars on LAI plots indicate one standard deviation from the mean; LAI values without error bars were estimated. Sagebrush plots were burned after sampling in 2007, and aspen were cut after measurements in 2008. LAI of the grass understory beneath the aspen was approximately 1.0 throughout the study.

measured LAI for each year. Rooting depth for the aspen was taken from previous studies in the watershed (Flerchinger et al., 1996) and assumed to remain unchanged after cutting as saplings quickly sprouted from the existing root stock. Root depth was set at $100 \mathrm{~cm}$ for the low sagebrush. Based on results from Flerchinger and Seyfried (2014), root depth of the mountain big sagebrush was set to $225 \mathrm{~cm}$ prior to the prescribed fire. Post-fire root depth of the recovering vegetation was estimated herein by a combination of the following: soil water extraction patterns from soil moisture profile measurements, and model sensitivity analyses comparing simulation results for a range of root depth to ET measurements from the EC system.

Continuous 31-year model runs (October 1982 through September 2013) were conducted for the analysis of vegetation disturbance on streamflow. This allowed 1 year for the model to 'spin up' and the assumed initial conditions to equilibrate with climatic conditions before the 1984-2013 analysis period. LAI prior to 2004 was taken as the average of the measured pre-disturbance LAI. Initiation of the growing season was adjusted each year based on date of complete snowcover ablation, but vegetation growth was not adjusted for yearly weather variations. Drift factors were applied to wintertime precipitation as described by Flerchinger and Cooley (2000) and Chauvin et al. (2011) to account for drifting of the snow, referred to as drift-adjusted precipitation. Snow drifts within the catchment are topographically driven, and no noticeable change in snow distribution was observed in the years following treatment as snow typically covered all vegetation during the winter, except in the immediate vicinity of the aspen EC tower. Therefore, catchment-scale changes in post-treatment sublimation due to changes in interception of precipitation and radiation (Veatch et al., 2009; Biederman et al., 2014a; and Harpold et al., 2014) were not expected.

\section{Streamflow analyses}

Correlations between pre-disturbance streamflow and watershed processes established by Chauvin et al. (2011) were used as a starting point to investigate the influence of vegetation disturbance on streamflow. Chauvin et al. (2011) demonstrated strong correlations between streamflow and (1) simulated percolation beyond the root zone using the SHAW model and (2) a combination of soil moisture deficit at the beginning of the water year and area-weighted, winter-spring precipitation (i.e. through March for the low sagebrush, April for the mountain big sagebrush, and May for the aspen). However, the correlation developed using soil moisture deficit was problematic for the current analysis as it would implicitly include the influence of the vegetation disturbance, whereas the analysis requires a measure independent of vegetation influence. Therefore, various multivariate linear regressions were investigated using the previous year's precipitation, temperature, vapour pressure deficit, and potential evaporation in lieu of soil moisture deficit. The regression models were calibrated to the period 1984 through 2001 and evaluated for the 6-year period immediately preceding disturbance (2002 through 2007). A one-sided $t$-test was used to determine whether the mean residuals during the evaluation period and post-disturbance period were significantly different from zero. A significant difference for the post-disturbance period would suggest that vegetation disturbance did indeed influence streamflow.

The regression between streamflow and simulated percolation beyond the root zone can be assumed to be independent of vegetation. Post-disturbance percolation was therefore simulated based on the actual vegetation and the average predisturbance vegetation. Streamflow was then estimated using the regression established for the pre-disturbance period. Presumably, post-disturbance residuals of estimated streamflow based on actual vegetation should not be significantly different from zero, whereas those using predisturbance vegetation would be significant if the disturbance had a significant influence on ET, percolation, and streamflow.

\section{RESULTS}

\section{Vegetation response}

Recovering post-fire vegetation for the low sagebrush zone was exclusively grasses and forbs; no shrubs were 
observed during the post-fire years as shown in Figure 3. Of the 16 low sagebrush point-intercept plots in the low sagebrush zone, four were consumed by the fire (Figure 2). Therefore, pre-fire and post-fire LAI values for the low sagebrush zone are separated into the plots that were burned and those that were not. A $t$-test comparing LAI of the burned and unburned plots in the low sagebrush zone at peak standing biomass indicated no significant difference in total LAI for any year. Not surprisingly, the year immediately following the fire did have the lowest $p$-value $(p=0 \cdot 11)$ although still not significant. The differences in shrub LAI between burned and unburned plots for the postfire years were highly significant $(p<0 \cdot 01)$.

Data plotted in Figure 3 show an increase in post-fire LAI for the low sagebrush plots, even for the unburned plots. Unfortunately, there are only 2 years of data (2005 and 2007) prior to the fire. It is logical that LAI would be lower during the 2007 drought year; one reason that 2005 might be low is that these data were collected by different personnel than the remainder of the data. Nevertheless, the effect of the apparently low estimates of LAI during the pre-fire years is discussed in a subsequent section.

Shrubs, predominately mountain big sagebrush and snowberry, constituted about half of the pre-fire LAI in the mountain big sagebrush zone. LAI measured prior to the fire was approximately 1.3 (Figure 3 ), which compares well with that of 1.2 reported previously for the site (Flerchinger and Cooley, 2000); average vegetation height prior to the fire in 2007 was $0.9 \mathrm{~m}$ and grew to nearly $0.6 \mathrm{~m}$ by 2012 . Unlike the low sagebrush zone, shrubs in the mountain big sagebrush zone did make some recovery but constituted only $25 \%$ of the LAI by the end of study period 6 years after the fire (Figure 3); post-fire shrub recovery was almost entirely snowberry, and little to no mountain big sagebrush was observed 6 years after the fire.

Leaf area index of the aspen trees was around 2.0 for most pre-fire years except for the drought year of 2007 (Figure 3). Aspen were quick to sprout from their existing root system after cutting and quickly recovered to their pre-cut LAI. By 2010, the second year after cutting, aspen LAI actually exceeded pre-cut levels and continued to increase until the relatively dry year of 2012. Aspen height at the EC system was approximately $4.5 \mathrm{~m}$ prior to cutting in 2008 and grew to $2.0 \mathrm{~m}$ by 2013 . The grass understory was consistently around 1.0 throughout the study (data not shown).

\section{Effect of root depth}

Chauvin et al. (2011) assumed that the effective root depth extended beyond the shallow $50-\mathrm{cm}$ soil of the low sagebrush zone to a depth of $100 \mathrm{~cm}$ through cracks and fissures of the rocky substrate. To assess the impact of this assumption, simulations for the low sagebrush zone were run for the study years herein with varying root depths and compared with the 50-cm TDR-measured soil water loss. Table I indicates very little difference in ET between simulations using $100-$ and $150-\mathrm{cm}$ rooting depth, and these do not significantly differ $(p>0 \cdot 10)$ for most years from the 50-cm TDR-measured soil water loss based on two-tailed paired $t$-tests of weekly simulated ET and soil water loss. Thus, roots at this site extract relatively little water from deeper than the $50-\mathrm{cm}$ profile. Unlike the mountain big sagebrush and aspen areas, snow does not accumulate through the winter in the low sagebrush zone, and there is not a big pulse of water into the soil profile in the spring. Therefore, the infiltrating water does not fully saturate and percolate beyond the soil profile except in very wet years, and the plants must rely on relatively shallow soil moisture. Indeed, the simulated wetting front reached the 100-cm depth only 2 of the 10 years (2006 and 2011). Therefore, results are relatively insensitive to the assumed rooting depth for the low sagebrush, and the $100-\mathrm{cm}$ prefire root depth used by Chauvin et al. (2011) is quite reasonable. Full recovery of this relatively shallow root system is to be expected within the first year following the fire, as demonstrated for a similar site by Seyfried and Wilcox (2006).

Cumulative soil water loss by depth measured to $235 \mathrm{~cm}$ by soil neutron probe in the mountain big sagebrush zone plotted for each growing season through 2012 in Figure 4a suggests a loss of rooting depth after the fire. During the two pre-fire years (2006 and 2007), approximately $87 \%$ of the total water extracted came for the top $160 \mathrm{~cm}$. However for 2008 , the first year after the fire, soil water loss measured to $160 \mathrm{~cm}$ accounts for $98 \%$ of the soil water loss, and water loss to $190 \mathrm{~cm}$ accounts for all of it. Years 2009 and 2010 also extracted noticeably less water from deeper in the profile than the pre-fire years, but by 2011, the roots were extracting very similarly to the pre-fire year of 2006. Because 2007 was such a dry year with very little recharge of the soil profile, the vegetation relied heavily on soil water stored deeper in the profile, and Figure 4a would suggest that the roots were extracting water beyond the $235-\mathrm{cm}$ measured neutron profile and the assumed rooting depth.

Figure $4 \mathrm{a}$ is contradictory to the analysis conducted by Flerchinger and Seyfried (2014) where post-fire ET for the mountain big sagebrush zone was simulated adequately using a rooting depth of $150 \mathrm{~cm}$ through 2011; however, they did not examine soil water extraction by depth. Thus, a sensitivity analysis of post-fire rooting depth on simulated ET was conducted for 2011 through 2013 as presented in Table II. Simulated ET for 2011 changes very little with increasing root depth, ranging from 502 to $509 \mathrm{~mm}$ for root depth spanning from $100 \mathrm{~cm}$ to $275 \mathrm{~cm}$. Weekly simulated ET for 2011 compared well with measured ET regardless of root depth; $p$-values from the two-tailed paired $t$-test comparing simulated and measured 
Table I. Cumulative evapotranspiration (ET) for each growing season (days 100 through 330) at the low sagebrush site computed by TDR-measured soil water loss within the $50-\mathrm{cm}$ profile and simulated by the SHAW model using measured LAI and varying root depths.

\begin{tabular}{|c|c|c|c|c|c|c|c|c|}
\hline \multirow{2}{*}{ Year } & \multirow{2}{*}{ Precip. (mm) } & \multirow{2}{*}{$\begin{array}{l}\text { ET from } \\
\text { TDR }(\mathrm{mm})\end{array}$} & \multicolumn{2}{|c|}{ Burned with $100-\mathrm{cm}$ roots } & \multicolumn{2}{|c|}{ Burned with $150-\mathrm{cm}$ roots } & \multicolumn{2}{|c|}{ Unburned with $100-\mathrm{cm}$ roots } \\
\hline & & & $\begin{array}{l}\text { Simulated } \\
\text { ET }(\mathrm{mm})\end{array}$ & $p$ (TDR) & $\begin{array}{l}\text { Simulated } \\
\text { ET }(\mathrm{mm})\end{array}$ & $p$ (TDR) & $\begin{array}{l}\text { Simulated } \\
\text { ET (mm) }\end{array}$ & $p$ (TDR) \\
\hline 2004 & 199 & 270 & 293 & $0 \cdot 488$ & 295 & $0 \cdot 463$ & 306 & $0 \cdot 306$ \\
\hline 2005 & 316 & 357 & 367 & 0.639 & 370 & $0 \cdot 580$ & 379 & $0 \cdot 384$ \\
\hline 2006 & 148 & 283 & 333 & $0 \cdot 070$ & 337 & $0 \cdot 052$ & 351 & $0 \cdot 024$ \\
\hline 2007 & 154 & 248 & 228 & $0 \cdot 362$ & 279 & $0 \cdot 334$ & 215 & $0 \cdot 107$ \\
\hline 2008 & 159 & 249 & 252 & 0.557 & 259 & $0 \cdot 420$ & 254 & $0 \cdot 512$ \\
\hline 2009 & 265 & 374 & 325 & $0 \cdot 334$ & 327 & $0 \cdot 353$ & 327 & $0 \cdot 330$ \\
\hline 2010 & 242 & 377 & 400 & 0.717 & 400 & 0.718 & 399 & 0.709 \\
\hline 2011 & 179 & 324 & 398 & 0.055 & 401 & 0.048 & 431 & 0.013 \\
\hline 2012 & 129 & 236 & 222 & 0.641 & 221 & 0.646 & 184 & 0.044 \\
\hline 2013 & 206 & 297 & 312 & 0.803 & 359 & 0.292 & 313 & 0.765 \\
\hline
\end{tabular}

Also shown is significance ( $p$-values) of paired $t$-tests comparing weekly simulated ET with that estimated by TDR-soil water loss. SHAW, Simultaneous Heat and Water; LAI, leaf area index; TDR, time domain reflectometry.
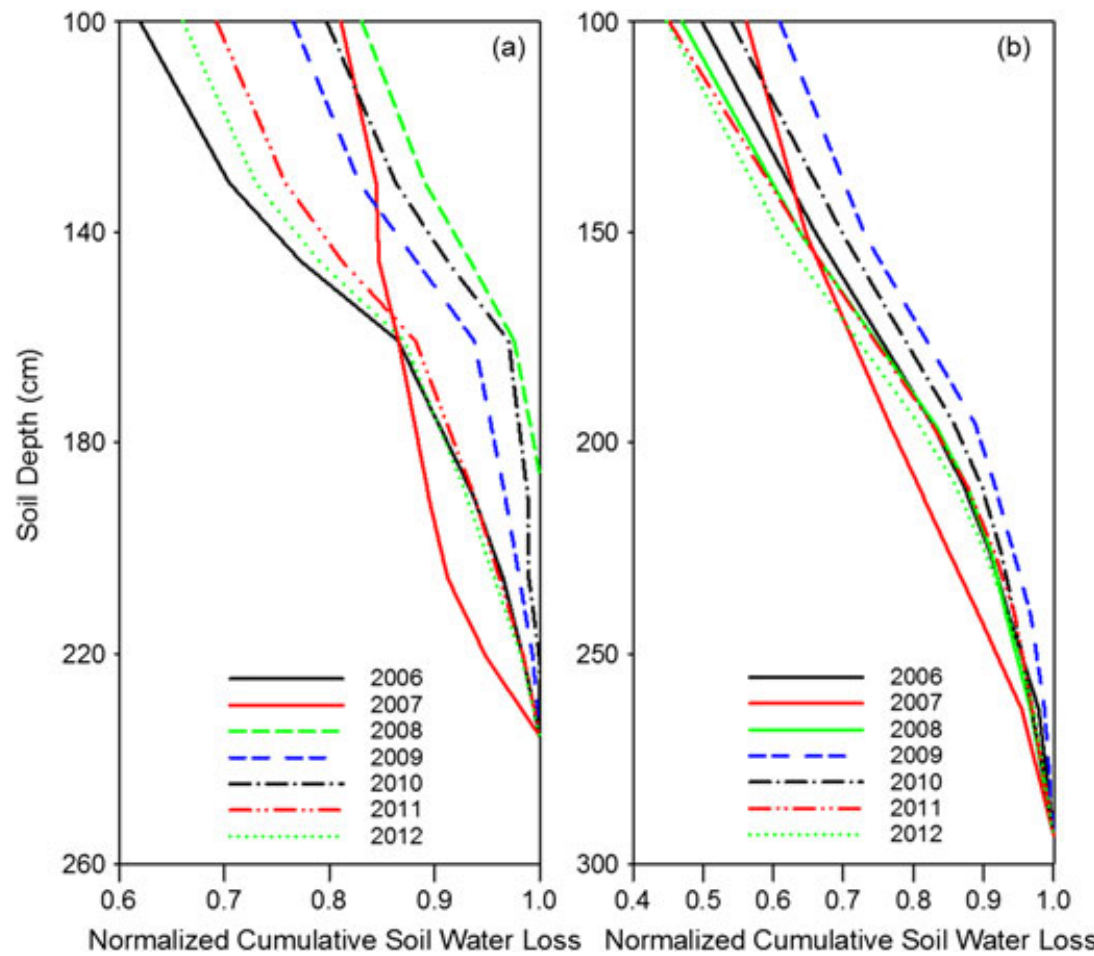

Figure 4. Soil water loss accumulated by soil depth and normalized for each growing season as measured in neutron access tubes for the (a) the mountain big sagebrush zone and (b) the aspen zone (profile is truncated above $100 \mathrm{~cm}$ to better focus on the deeper profile; solid lines indicate pre-treatment years).

weekly ET exceeded 0.49 for all root depths tested. Thus ET could be simulated adequately for 2011 using any reasonably selected root depth; although roots may have grown beyond $200 \mathrm{~cm}$ deep, there was sufficient precipitation $(747 \mathrm{~mm}$; Figure 3 ) and soil moisture that a rooting depth of $100 \mathrm{~cm}$ could meet ET demand. In contrast, simulated ET for 2012, which had only $432 \mathrm{~mm}$ of precipitation, is much more sensitive to root depth and ranges from 325 to $370 \mathrm{~mm}$. Simulated ET for all root depths less than $225 \mathrm{~cm}$ during 2012 is significantly different from measured ET $(p<0 \cdot 05)$. Thus, the evidence suggests that over time, roots had grown to at least $225 \mathrm{~cm}$ by 2012 . Inspection of Table II indicates that a $200-\mathrm{cm}$ root depth compares best with measurements for 2013, but as with 2011, none are significantly different from the measured ET. Therefore, based on Figure $4 \mathrm{a}$ and the 
Table II. Cumulative growing season evapotranspiration (ET) for the mountain big sagebrush area measured by eddy covariance (EC) and simulated using root depth varying from 100 to $275 \mathrm{~cm}$, and results of a paired $t$-test for comparing simulated and measured weekly ET values.

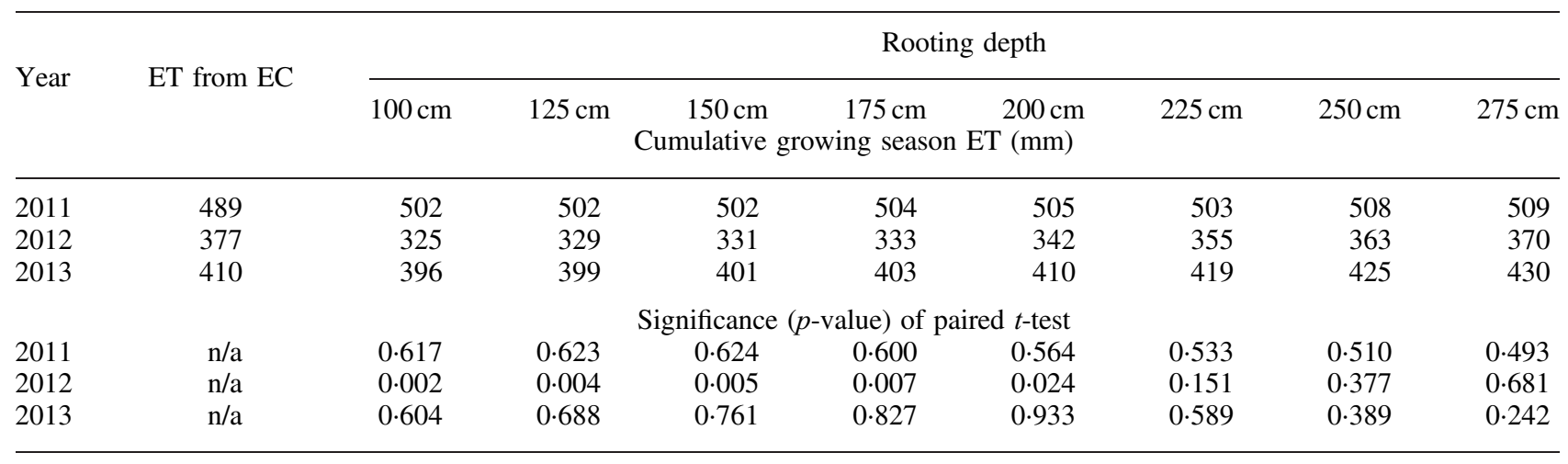

sensitivity analysis in Table II, post-fire root depth in the mountain big sagebrush zone was set to $150 \mathrm{~cm}$ for 2008 through 2010 and increased to $225 \mathrm{~cm}$ during 2011.

While it is clear that there was a loss of rooting depth for the mountain big sagebrush zone, Figure $4 \mathrm{~b}$ indicates very little difference in the relative contribution of the deeper depths for the aspen between different years. Although the fraction of water extracted from the deeper depths was slightly less for the first and second years (2009 and 2010) after cutting the aspen compared with other years, the difference is not nearly as dramatic as for the mountain big sagebrush site. Both the mountain big sagebrush and aspen sites lost a significant amount of deep soil moisture during the drought year of 2007 (Figure 4).

\section{Low sagebrush site ET}

As expected, simulated ET for the low sagebrush zone plotted in Figure 5 is greater than TDR-measured soil water loss because the simulated root depth is greater than the 50$\mathrm{cm}$ measured profile, even though it is not significantly different for most years (Table I). The only years that are statistically significant $(p<0 \cdot 10)$ are very wet years $(2006$ and 2011) when the simulated soil profile wetted well beyond $50 \mathrm{~cm}$, and simulated soil water extraction by roots was beyond the measured profile. Simulated ET based on root depth, LAI, and plant composition of the burned plots is similar to that for the unburned plots for most years. Given the fact that there was no significant difference between total LAI between the burned and unburned plots, there is no real difference in simulated ET for the burned versus unburned areas within the low sagebrush zone. Indeed, cumulative ET is very insensitive to LAI for most years owing to the limited rooting depth. When the questionably low pre-fire LAI values mentioned previously were replaced with the higher values measured in 2008 (Figure 3), only a slight increase in ET (less than $3 \%$ in most years) was simulated.

\section{Mountain big sagebrush site ET}

Simulated pre-fire ET plotted in Figure 6 for the mountain big sagebrush zone changes very little whether using actual vegetation conditions or the average of all pre-fire years, and both compare favourably with ET measured using EC. During the first year after the fire (2008), ET from soil water loss compared much more favourably with EC measurements and simulations, after roots were no longer extracting water from the deeper soil depths. The SHAW simulation using pre-fire LAI and root depth had modestly more ET than that for post-fire vegetation conditions. By the second year after the fire (2009), ET estimated from soil water was less than for the other methods, suggesting that roots grew beyond the measurement depth (Flerchinger and Seyfried, 2014). Simulated ET using pre-fire vegetation remained higher than post-fire vegetation through the second year. Not much change is evident between the second and third years after the fire (2009 and 2010). Simulated ET tracks with the EC measurements reasonably well, while pre-fire vegetation still results in higher simulated ET. For the fourth and subsequent years after the fire, ET simulated using the actual vegetation approaches that simulated by pre-fire vegetation conditions. During the growing season immediately after the fire, simulated ET using pre-fire vegetation was $15 \%$ greater than simulations using measured post-fire vegetation conditions. This difference decreased to $4 \%$ for the pre-fire vegetation during the relatively wet 2011 growing season, and by 2013, simulated ET was 3\% higher using post-fire conditions.

Consistent with the results plotted in Figure 6, weekly ET simulated using post-fire root depth and measured LAI was not significantly different from ET measured by EC, as shown for the post-fire paired $t$-tests in Table III. By contrast, weekly ET simulated using pre-fire vegetation was significantly different from EC measurements $(p<0.05)$ for postfire years 2008 and 2010, indicating that post-fire ET is significantly less as a result of the change in vegetation as 


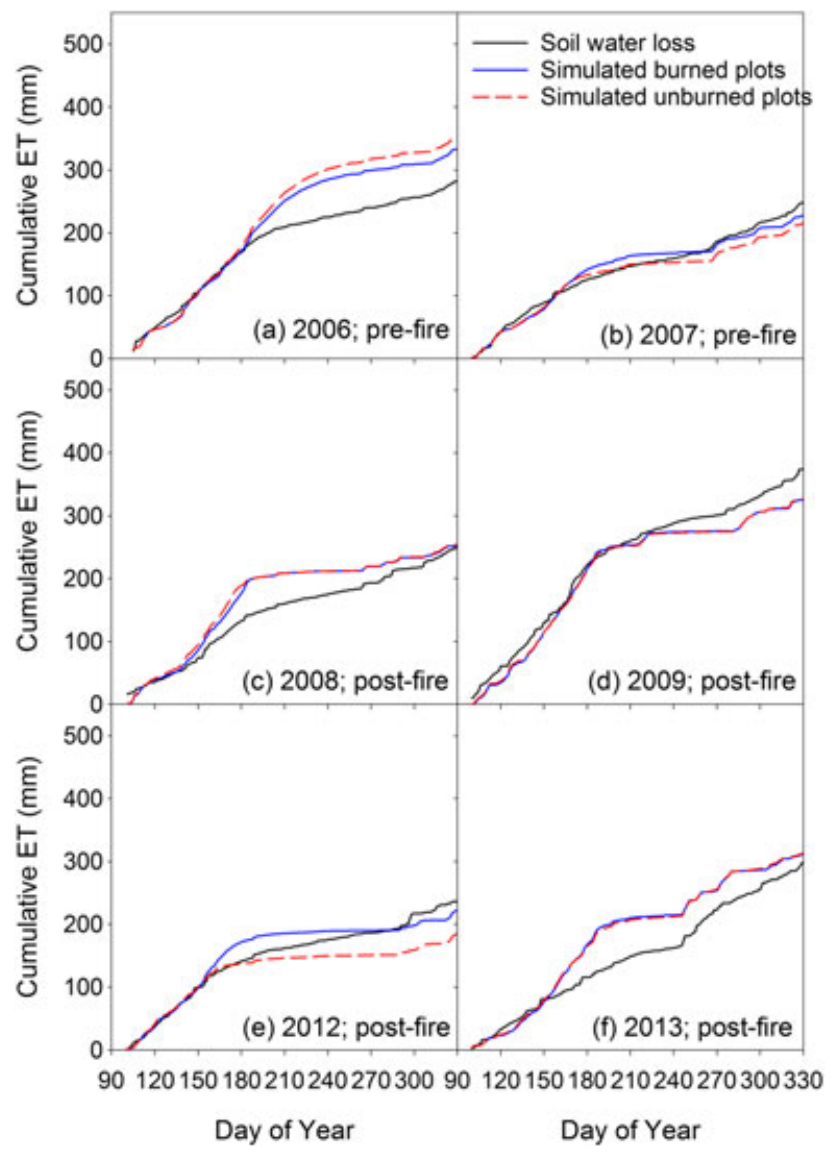

Figure 5. Cumulative daily evapotranspiration (ET) during selected years for the low sagebrush zone based on soil water loss within the $100-\mathrm{cm}$ time domain reflectometry profile and model simulation based on leaf area index measured in each of the burned and unburned plots.

indicated in Figure 7 for 2008. The paired $t$-tests indicate whether residuals are significantly different from zero, or alternatively, whether the data plot significantly above or below the 1:1 line. Simulated data using actual vegetation conditions for 2008 plot along the 1:1 line when compared with EC measurements; however, the 2008 pre-fire simulation consistently plot on or above the 1:1 line. Although cumulative ET for 2009 simulated with pre-fire vegetation was higher than the $\mathrm{EC}$ measurements, it was not significantly different. The reason that the 2009 pre-fire simulation is not significantly different from zero is largely related to the fact that the timing of simulated ET for either pre-fire or actual vegetation is off (Figure 6), resulting in more scatter around the 1:1 line, as shown for the 2009 prefire simulation in Figure 7. By 2012, cumulative ET simulated using pre-fire conditions is almost identical to that measured by EC and is actually lower during 2013 than either measured ET or that simulated using actual vegetation conditions.

Inspection of Table III indicates that soil water loss measured in the 120-cm TDR soil profile is less than simulated ET and ET measured by EC for all years except

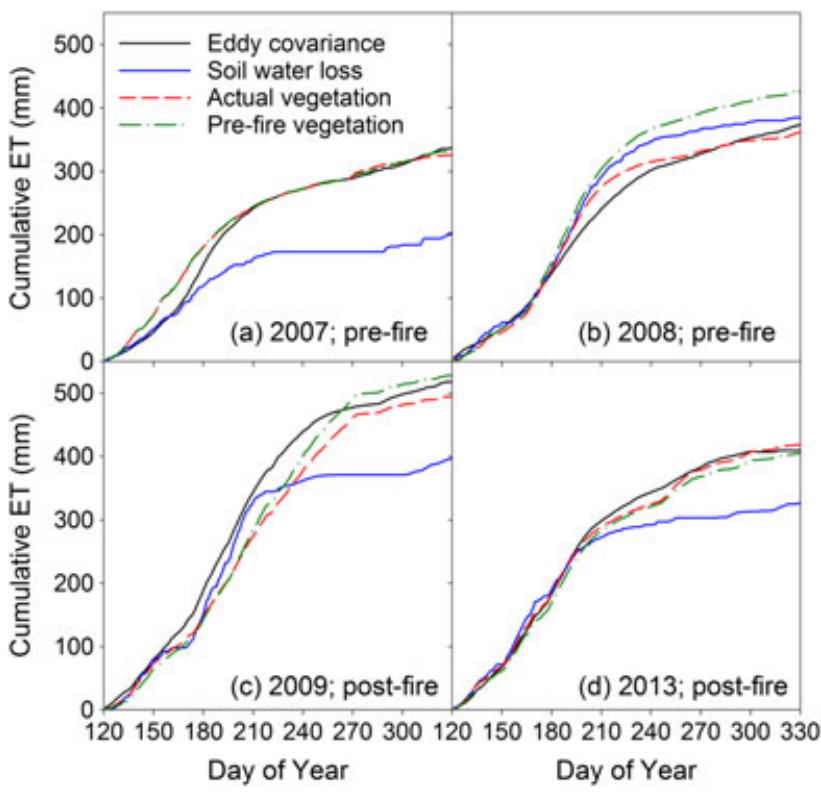

Figure 6. Cumulative daily evapotranspiration (ET) during selected years for the mountain big sagebrush zone computed from the following: eddy covariance; soil water loss within $125-\mathrm{cm}$ time domain reflectometry profile; and model simulations based on average pre-fire vegetation (root depth and leaf area index) and actual vegetation. Comparisons between simulated and measured ET for additional years can be found in Flerchinger and Seyfried (2014).

2008, the year immediately following the fire. Soil water loss is not significantly less than simulated ET using actual vegetation for $2009(p=0 \cdot 108)$ due mostly to the incorrect timing of simulated ET as mentioned earlier. Based on the results in Figure 6 and Table III showing soil water extraction being significantly less than other methods of estimating ET, it is clear that vegetation extracted water from well beyond the $120-\mathrm{cm}$ measured profile for all years except 1 or 2 years immediately following the fire, further confirming post-fire loss of rooting depth shown in Figure 4a discussed previously.

\section{Aspen ET}

There is very little difference between simulated ET for the years before aspen cutting whether using actual vegetation conditions or the average of all pre-cut years, as shown in Table IV. As noted by Flerchinger and Seyfried (2014), ET measured by EC during 2008 falls short of that based on TDR-measured soil water loss and simulated ET; this is due in part to limited fetch for the aspen, even under the best conditions, and the burned sagebrush surrounding the aspen area contributing to the flux measurements. EC measurements in 2006 may have experienced similar problems with fetch as well. Unfortunately, instrumentation difficulties caused large gaps in the 2007 EC data that could not reliably be filled. Height of the EC system was lowered post-cutting, thereby reducing the footprint of the observed fluxes and influence of the surrounding sagebrush. 
Table III. Cumulative evapotranspiration (ET) for each growing season (days 120 through 330) at the mountain big sagebrush site: computed by eddy covariance (EC) and TDR-measured soil water loss within the 120 -cm profile and simulated by the SHAW model using actual vegetation conditions and average pre-fire LAI and root depth.

\begin{tabular}{|c|c|c|c|c|c|c|c|c|c|}
\hline \multirow{2}{*}{ Year } & \multirow{2}{*}{ Precip. (mm) } & \multirow{2}{*}{$\mathrm{EC}(\mathrm{mm})$} & \multirow{2}{*}{$\mathrm{TDR}(\mathrm{mm})$} & \multirow{2}{*}{ Actual vegetation (mm) } & \multirow{2}{*}{ Pre-fire veg. (mm) } & \multicolumn{2}{|c|}{ Actual vegetation } & \multicolumn{2}{|c|}{ Pre-fire vegetation } \\
\hline & & & & & & $p(\mathrm{EC})$ & $p$ (TDR) & $p(\mathrm{EC})$ & $p$ (TDR) \\
\hline 2004 & 202 & $\mathrm{n} / \mathrm{a}$ & 334 & 514 & 512 & $\mathrm{n} / \mathrm{a}$ & $0 \cdot 001$ & $\mathrm{n} / \mathrm{a}$ & $0 \cdot 001$ \\
\hline 2005 & 298 & $\mathrm{n} / \mathrm{a}$ & 402 & 473 & 471 & $0 \cdot 166^{\mathrm{a}}$ & $0 \cdot 126$ & $0 \cdot 189^{\mathrm{a}}$ & $0 \cdot 132$ \\
\hline 2006 & 153 & 477 & 360 & 452 & 451 & $0 \cdot 343$ & $0 \cdot 002$ & $0 \cdot 336$ & $0 \cdot 002$ \\
\hline 2007 & 133 & 337 & 204 & 326 & 333 & $0 \cdot 645$ & $<0 \cdot 001$ & $0 \cdot 447$ & $<0 \cdot 001$ \\
\hline 2008 & 154 & 374 & 385 & 368 & 426 & 0.900 & $0 \cdot 526$ & $0 \cdot 035$ & $0 \cdot 015$ \\
\hline 2009 & 255 & 517 & 397 & 498 & 528 & $0 \cdot 585$ & $0 \cdot 108$ & $0 \cdot 372$ & $0 \cdot 024$ \\
\hline 2010 & 312 & 461 & 386 & 482 & 520 & $0 \cdot 387$ & $0 \cdot 018$ & $0 \cdot 038$ & $0 \cdot 003$ \\
\hline 2011 & 159 & 489 & 426 & 503 & 524 & 0.607 & $0 \cdot 086$ & $0 \cdot 163$ & $0 \cdot 031$ \\
\hline 2012 & 110 & 377 & 283 & 355 & 378 & $0 \cdot 158$ & 0.002 & 0.443 & 0.001 \\
\hline 2013 & 214 & 410 & 326 & 419 & 405 & $0 \cdot 612$ & 0.002 & 0.427 & 0.005 \\
\hline
\end{tabular}

Also shown is significance ( $p$-values) of paired $t$-tests comparing simulated and measured weekly ET. Simulated root depth for the actual vegetation was to $150 \mathrm{~cm}$ for years 2008 through 2011 and $225 \mathrm{~cm}$ for all other years; simulated root depth for pre-fire vegetation was $225 \mathrm{~cm}$.

SHAW, Simultaneous Heat and Water; LAI, leaf area index; TDR, time domain reflectometry.

${ }^{\text {a }}$ Denotes $p$-values for weekly ET after EC system was operational (day 229).

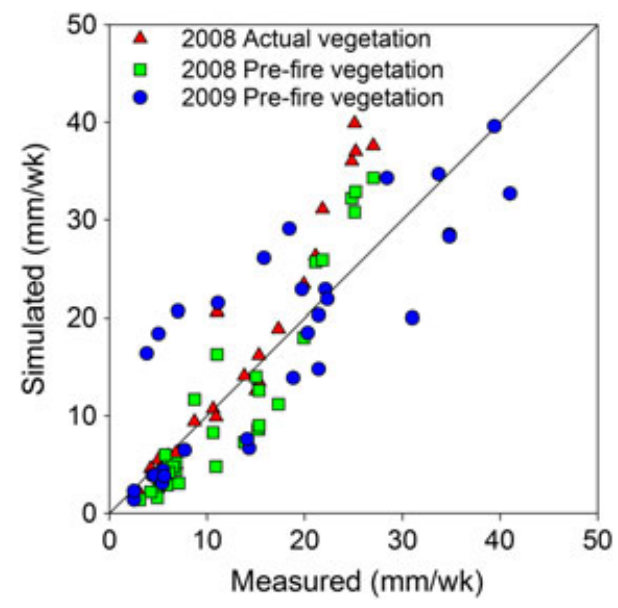

Figure 7. Measured weekly evapotranspiration (ET) for 2008 and 2009 versus simulated weekly ET using actual vegetation and average pre-fire vegetation (paired $t$-tests presented in the tables examine whether the data significantly plot above or below the 1:1 line).

The increase in ET may be a result of resurgence in grasses after fall precipitation, which was not accounted for by the model. Flerchinger and Seyfried (2014) suggested that the years that the TDR-measured soil water loss did not show an increase in water use may be attributed to the fact that the TDR-measured soil water loss was set to zero during days with precipitation. Also, the ET response may be from soil moisture shallower than the 10-cm TDR soil probe.

Simulated ET using cut aspen conditions compares well with ET measured by EC for all post-cutting years (Table IV). Simulated ET using pre-cut conditions also compares favourably with ET measured by EC, except being approximately $10 \%$ higher for 2009 , which is marginally significant $(p=0.063)$. By 2010 , LAI of the new aspen shoots actually surpassed pre-cut conditions (Figure 3), and there is very little difference between simulations using actual vegetation conditions and precut conditions (Table IV). Simulated ET using either actual vegetation or pre-cut conditions compares favourably with TDR-measured soil water loss for most years, with 2009 and 2011 being the exceptions; the difference between pre-cut simulated ET and TDRmeasured ET for 2009 is highly significant $(p=0.002)$. All told, the results suggest that cutting the aspen had little effect on ET except for the year immediately following cutting.

\section{Streamflow}

Stepwise regression analysis for 1984-2001 streamflow conducted using water-year precipitation measured at D03 and $\mathrm{J} 10$, precipitation adjusted for snow drifting, temperature, vapour pressure deficit, and potential evaporation confirmed the work of Chauvin et al. (2011) that drift-adjusted winterspring precipitation is the single most important factor influencing streamflow in Upper Sheep Creek $\left(r^{2}=0 \cdot 68\right.$, $p<0.01$ for winter precipitation $>300 \mathrm{~mm}$; Figure $8 \mathrm{a}$ ). Precipitation measured at J10 from the previous water year (lag-1 precipitation) was selected as the next most important independent variable $(p=0 \cdot 01)$, increasing the $r^{2}$ to 0.83 . In the absence of lag-1 J10 precipitation, lag-1 average vapour pressure deficit and lag-1 potential evaporation were significant, but not in combination with it.

Dynamics of measured annual streamflow plotted in Figure 9 were captured by streamflow estimates from the multivariate linear regression analysis. Mean Residual streamflow (MR, i.e. model minus observed) during the 6year evaluation period is $-2.8 \mathrm{~mm}$ while that for the 6 -year 
Table IV. Cumulative evapotranspiration (ET) for each growing season (typically 165 through 274) at the aspen site: computed by eddy covariance (EC) and TDR-measured soil water loss within the 180-cm profile and simulated by the SHAW model using actual vegetation conditions and average pre-cut LAI.

\begin{tabular}{|c|c|c|c|c|c|c|c|c|c|}
\hline \multirow{2}{*}{ Year } & \multirow{2}{*}{ Precip. (mm) } & \multirow{2}{*}{$\mathrm{EC}(\mathrm{mm})$} & \multirow{2}{*}{ TDR (mm) } & \multirow{2}{*}{$\begin{array}{c}\text { Actual } \\
\text { vegetation }(\mathrm{mm})\end{array}$} & \multirow{2}{*}{$\begin{array}{l}\text { Average } \\
\text { pre-cut (mm) }\end{array}$} & \multicolumn{2}{|c|}{ Actual vegetation } & \multicolumn{2}{|c|}{ Pre-cut vegetation } \\
\hline & & & & & & $p(\mathrm{EC})$ & $p(\mathrm{TDR})$ & $p(\mathrm{EC})$ & $p$ (TDR) \\
\hline 2004 & 59 & $\mathrm{n} / \mathrm{a}$ & 445 & 475 & 471 & $\mathrm{n} / \mathrm{a}$ & $0 \cdot 246$ & $\mathrm{n} / \mathrm{a}$ & $0 \cdot 298$ \\
\hline 2005 & 60 & $\mathrm{n} / \mathrm{a}$ & 438 & 469 & 465 & $\mathrm{n} / \mathrm{a}$ & 0.996 & $\mathrm{n} / \mathrm{a}$ & 0.928 \\
\hline 2006 & 51 & 400 & 437 & 470 & 467 & $0 \cdot 083$ & $0 \cdot 287$ & $0 \cdot 100$ & $0 \cdot 329$ \\
\hline 2007 & 40 & $\mathrm{n} / \mathrm{a}$ & 262 & 282 & 284 & $\mathrm{n} / \mathrm{a}$ & $0 \cdot 646$ & $\mathrm{n} / \mathrm{a}$ & 0.794 \\
\hline 2008 & 19 & 369 & 447 & 442 & 443 & $<0.001$ & $0 \cdot 684$ & $<0 \cdot 001$ & $0 \cdot 726$ \\
\hline 2009 & 70 & 435 & 395 & 434 & 478 & 0.951 & $0 \cdot 062$ & $0 \cdot 063$ & $0 \cdot 002$ \\
\hline 2010 & 31 & 445 & 427 & 453 & 458 & $0 \cdot 269$ & $0 \cdot 184$ & $0 \cdot 121$ & $0 \cdot 168$ \\
\hline 2011 & 14 & 437 & 463 & 423 & 425 & $0 \cdot 254$ & $0 \cdot 028$ & $0 \cdot 273$ & $0 \cdot 046$ \\
\hline 2012 & 8 & 432 & 431 & 427 & 436 & $0 \cdot 801$ & $0 \cdot 887$ & 0.752 & 0.752 \\
\hline 2013 & 147 & 465 & 429 & 463 & 483 & $0 \cdot 806$ & 0.431 & 0.430 & $0 \cdot 100$ \\
\hline
\end{tabular}

Also shown is significance ( $p$-values) of paired $t$-tests comparing simulated and measured weekly ET. Plots comparing simulated and measured ET can be found in Flerchinger and Seyfried (2014).

SHAW, Simultaneous Heat and Water; LAI, leaf area index; TDR, time domain reflectometry.

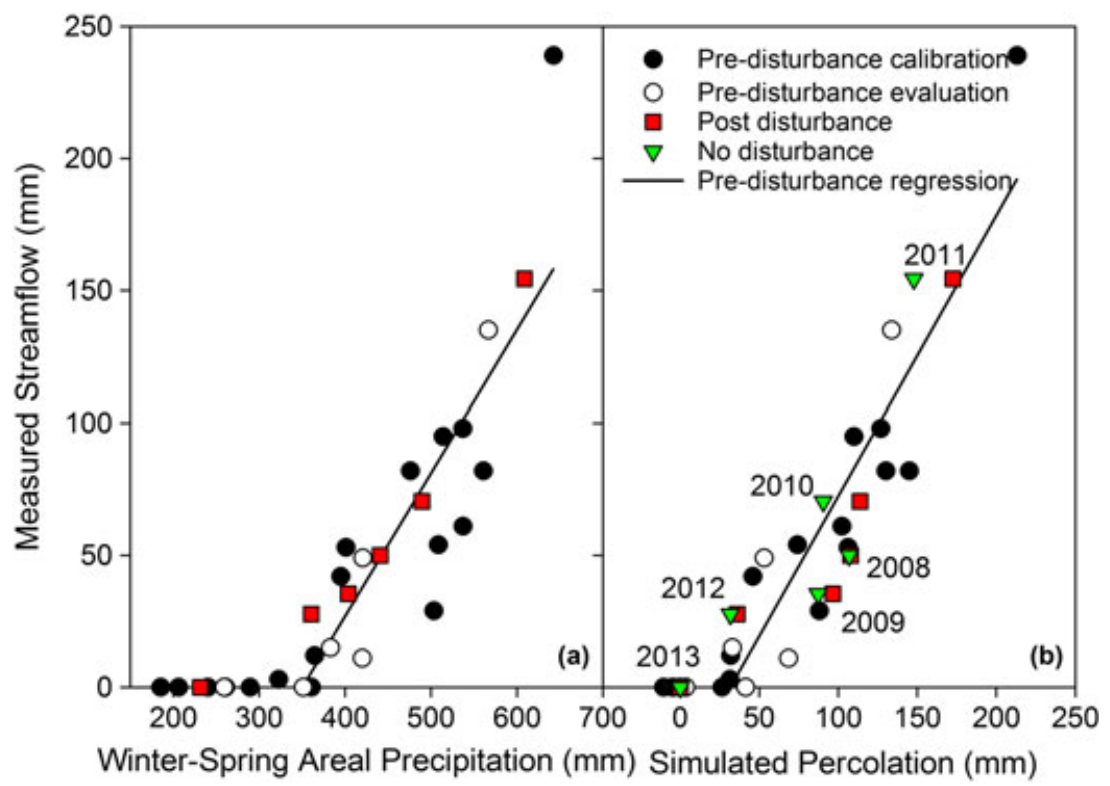

Figure 8. Measured streamflow versus (a) areal-weighted winter-spring precipitation and (b) simulated areal-weighted percolation beyond the root zone for pre-disturbance calibration years (1984-2001), pre-disturbance evaluation years (2002-2007), and post-disturbance years (2008-2013). Percolation was simulated using actual post-disturbance vegetation and average pre-disturbance vegetation (i.e. no disturbance).

post-disturbance period is $-9.7 \mathrm{~mm}$. Thus, average postdisturbance streamflow is approximately $20 \%$ higher than estimated. A $t$-test to discern whether the residuals are significantly different from zero yielded $p=0.300$ and $p=0.055$, respectively, indicating that vegetation disturbance is marginally significant. Inspection of Figure 9 and evaluation of the entire record indicated that the only 6-year period with residuals significantly greater than zero is 1994 through 1999 (MR $=15.4 \mathrm{~mm}, p=0.047)$. The reason that this period is significant might be attributed to recovery of the catchment following extended drought conditions; however, lag terms greater than 1 year were not found to be significant in the regression.

Although the aspen make up the smallest portion of the watershed, its contribution to streamflow is greatest as shown in Table $\mathrm{V}$ owing to the large snow drift; contribution from the low sagebrush and mountain big sagebrush zones is negligible except during wet years. Area-weighted average post-disturbance percolation beyond the root zone is approximately $12 \%$ higher using post-disturbance vegetation than using pre-disturbance vegetation (Table V). Not surprisingly, there is not much 


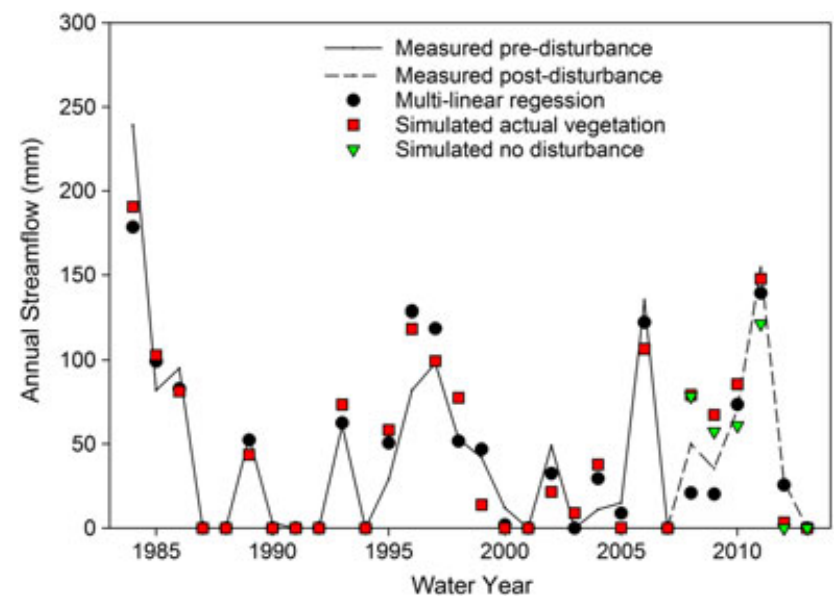

Figure 9. Measured annual streamflow along with estimated streamflow based on 1984-2001 regression analyses. Estimated streamflow are based on (1) multivariate linear regression, (2) simulated areal percolation using actual vegetation, and (3) and simulated areal percolation during postdisturbance years assuming no vegetation disturbance.

increase in simulated percolation for any of the sites immediately following the fire (2008) or aspen cutting (2009). A year of reduced ET resulting in reduced soil moisture deficit at the beginning of the water year is necessary for an increase in snowmelt percolation beyond the root zone (Flerchinger and Clark, 2003; Chauvin et al., 2011). Comparison of soil moisture storage on 1 October for the treated and untreated simulations 1 year posttreatment indicated that the cut aspen soil profile stored $4 \mathrm{~cm}$ more soil moisture, the burned mountain big sagebrush profile contained $3 \mathrm{~cm}$ more water, and the burned low sagebrush contained $1 \mathrm{~cm}$ more water. However, the simulated soil profile absorbed all of the 2009 snowmelt water in the low and mountain big sagebrush zones, so there was relatively little response in simulated percolation beyond the root zone until 2010 (Table V and Figure 8b).

Simulated areal average percolation from Table V was regressed with measured annual streamflow, as shown in Figure 8b. Mean Residuals (MR's) of the streamflow based on simulated percolation plotted in Figure 9 are $-5.8 \mathrm{~mm}$ $(p=0.27)$ for the evaluation period, $7.5 \mathrm{~mm}(p=0.22)$ for the post-disturbance using actual vegetation, and $-3.3 \mathrm{~mm}$ $(p=0.38)$ for post-disturbance using pre-disturbance vegetation. Thus, measured streamflow is greater than that predicted by the pre-disturbance vegetation, but not significantly so. However, the increase in estimated streamflow between post-disturbance and pre-disturbance vegetation is $10.8 \mathrm{~mm}$ (approximately 20\%), which is consistent with the increased streamflow based on the multivariate linear time trend analysis mentioned previously. As with the time trend analysis, the only 6-year period where residuals are significantly different from zero immediately follows the extended drought period (1993-1998; MR =17.3 mm, $p=0.02$ ).

It is possible that a more pronounced response might have been observed if the aspen and sagebrush had been burned in the fall of 2009 just prior to the two wetter years of 2010 and 2011. Simulations indicate that the predicted percolation response would have been lower for the 2010 run-off season (105 $\mathrm{mm}$ areal average) because of higher ET from an undisturbed 2009 growing season. Predicted percolation for 2011 (174 mm areal average) was almost identical to that based on the observed vegetation partly because the assumed root depth for the mountain big sagebrush zone was identical in both cases $(150 \mathrm{~cm})$. Although more percolation was predicted during 2011 for the aspen assuming a 2009 disturbance $(912 \mathrm{~mm})$, it covers

Table V. Measured streamflow $(\mathrm{mm})$ and simulated percolation $(\mathrm{mm})$ beyond the root zone based on actual vegetation and average of undisturbed vegetation conditions.

\begin{tabular}{|c|c|c|c|c|c|c|c|c|c|}
\hline \multirow[t]{3}{*}{ Water year } & \multirow[t]{3}{*}{ Streamflow } & \multicolumn{8}{|c|}{ Simulated percolation beyond root zone } \\
\hline & & \multicolumn{4}{|c|}{ Actual vegetation } & \multicolumn{4}{|c|}{ Undisturbed vegetation } \\
\hline & & $\begin{array}{l}\text { Low } \\
\text { sagebrush }\end{array}$ & $\begin{array}{c}\text { Mountain big } \\
\text { sagebrush }\end{array}$ & Aspen & $\begin{array}{l}\text { Areal } \\
\text { average }\end{array}$ & $\begin{array}{l}\text { Low } \\
\text { sagebrush }\end{array}$ & $\begin{array}{c}\text { Mountain big } \\
\text { sagebrush }\end{array}$ & Aspen & $\begin{array}{l}\text { Areal } \\
\text { average }\end{array}$ \\
\hline 2004 & 11 & 1 & -6 & 480 & 69 & 1 & -6 & 480 & 69 \\
\hline 2005 & 15 & 1 & 6 & 215 & 33 & 1 & 5 & 218 & 33 \\
\hline 2006 & 135 & 97 & -5 & 519 & 134 & 120 & -5 & 522 & 131 \\
\hline 2007 & 0 & -4 & -6 & 50 & 3 & -2 & -6 & 50 & 3 \\
\hline 2008 & 50 & -1 & -5 & 755 & 108 & -1 & -5 & 749 & 107 \\
\hline 2009 & 35 & 0 & 0 & 664 & 97 & 0 & -3 & 605 & 87 \\
\hline 2010 & 70 & 0 & 62 & 669 & 114 & 0 & 21 & 585 & 90 \\
\hline 2011 & 154 & 2 & 159 & 887 & 173 & 5 & 102 & 824 & 148 \\
\hline 2012 & 28 & 0 & -30 & 304 & 36 & -1 & -35 & 282 & 32 \\
\hline 2013 & 0 & 0 & -21 & -36 & 0 & 0 & -18 & -36 & 0 \\
\hline
\end{tabular}

Negative values of percolation indicate net water movement into the root zone from below. 
only a small portion of the watershed, resulting in only a small increase in areal average percolation.

\section{DISCUSSION AND CONCLUSIONS}

The impact of a prescribed fire and subsequent aspen cutting on ET and streamflow was assessed for a small mountainous catchment by capitalizing on the unique long-term knowledge base developed for the Upper Sheep Creek Catchment, a 26-ha headwater catchment dominated by low sagebrush, mountain big sagebrush, and aspen within the Reynolds Creek Experimental Watershed. The 2007 prescribed fire consumed $100 \%$ of the mountain big sagebrush area and approximately $21 \%$ of the low sagebrush area. The aspen, which were mostly untouched by the fire, were cut in the fall of 2008 .

Although no post-fire shrub recovery was observed 6 years after the fire in the low sagebrush zone, LAI (Figure 3) and root depth appear to have recovered in this zone within 1 year after the fire. Shrubs in the mountain big sagebrush zone were destroyed by the fire, resulting in a loss of rooting depth; no mountain big sagebrush was found within the LAI plots 6 years post-fire, but snowberry constituted approximately $25 \%$ of the peak LAI by the end of the study period. Based on observed soil water profiles (Figure 4a) and model simulations (Table II), root depth in the mountain big sagebrush zone was approximately $150 \mathrm{~cm}$ the first year postfire and took 4 years to recover to its pre-fire depth of $225 \mathrm{~cm}$. New vegetation in the mountain big sagebrush zone consisting of grasses and forbs replaced the deep-rooted shrubs; shrub recovery required time to re-establish roots deep within the profile, as reported for a similar site by Seyfried and Wilcox (2006). Aspen quickly sprouted from their existing roots after cutting and exceeded their pre-cut LAI levels 2 years after cutting the aspen (Figure 3).

Using the groundwork laid by Flerchinger and Seyfried (2014) and Chauvin et al. (2011), the effect of vegetation disturbance on ET and streamflow was assessed by comparing model simulations for pre-disturbance and post-disturbance vegetation conditions with measured soil water loss, ET, and streamflow. Hydrologic response of post-disturbance ET depended heavily on the loss of rooting depth caused by the disturbance. Because LAI and root depth in the low sagebrush zone recovered quickly after the fire, no significant difference was found in ET from the low sagebrush zone owing to the fire. ET from the mountain big sagebrush zone was estimated to be $15 \%$ less owing to the loss of vegetation and root depth the first year after the fire and decreased to $4 \%$ less by 4 years after the fire, at which time weekly ET simulated using pre-fire conditions was no longer significantly different from ET measured by EC.

Aspen trees, on the other hand, are able to sprout shoots from their roots after a disturbance, whether by fire or cutting, and can recover quickly. ET from the aspen was estimated to be approximately $10 \%$ less the first year after cutting compared with if it had not been cut. Model simulations using observed aspen conditions were shown to accurately simulate ET both before and after aspen cutting, giving confidence in the model's representation of changing site conditions. Indeed, while simulated weekly ET using observed aspen conditions compared well with TDR-measured soil water loss, simulated ET using pre-cut aspen conditions were significantly more during the first year after cutting. Thus, ET in the aspen recovered to pretreatment conditions much quicker than in the mountain big sagebrush area. This is in stark contrast to observations made in much wetter climates (1000- to 2000-mm precipitation) by Keppeler and Ziemer (1990), who reported 5 years for water yield to recover to pre-logging conditions for coniferous forests, and Moore and Wondzell (2005) and Zhang et al. (2012) who reported as much as 10 to 20 years to return to pre-harvest conditions. Conversely, Biederman et al. (2015) showed no response in streamflow after coniferous tree mortality in multiple catchments receiving approximately $800-\mathrm{mm}$ precipitation, and in some cases, streamflow was shown to increase.

The two analyses evaluating post-disturbance streamflow yielded mixed results. While time trend analysis based on multivariate linear regressions suggested marginally significant $(p=0.055)$ increased streamflow during the six postdisturbance years, the analysis using a process-based model was not statistically significant. Both approaches however estimated approximately a $20 \%$ increase in post-disturbance streamflow compared with undisturbed conditions.

A marginal response in streamflow for this site is consistent with observations summarized by Wilcox (2002), who suggests that there is little potential for increased streamflow from shrub control where annual precipitation is less than $500 \mathrm{~mm}$. The Upper Sheep Creek catchment is on the threshold of this boundary, and indeed, there is little potential for increased streamflow contribution from the sagebrush zone where the soil profile can absorb much of the precipitation pulse in most years. In such arid rangeland systems, plants tend to use all available water in the soil profile in most years (Wilcox, 2002; Huxman et al., 2005; Wilcox and Thurow, 2006), and there is little potential to increase streamflow for more than a few years. While the aspen zone may have the potential to produce a more pronounced response in streamflow, its rapid postdisturbance recovery and relatively small coverage within the watershed make for a limited response.

\section{ACKNOWLEDGEMENTS}

We thank the Owyhee Field Office and Idaho State Office of the USDI Bureau of Land Management for assistance in writing the Environmental Assessments and conducting the 
prescribed fire within the Upper Sheep Creek catchment. USDA is an equal-opportunity provider and employer. The authors declare no conflict of interest.

\section{REFERENCES}

Biederman JA, Brooks PD, Harpold AA, Gutmann E, Gochis DJ, Reed DE, Pendall E. 2014a. Multi-scale observations of snow accumulation and peak snowpack following widespread, insect-induced lodgepole pine mortality. Ecohydrology 7: 150-162.

Biederman JA, Harpold AA, Gochis DJ, Ewers BE, Reed DE, Papuga SA, Brooks PD. 2014b. Increased evaporation following widespread tree mortality limits streamflow response. Water Resources Research 50: 5395-5409.

Biederman JA, Somor AJ, Harpold AA, Gutmann ED, Breshears DD, Troch PA, Gochis DJ, Scott RL, Meddens AJH, Brooks PD. 2015 Recent tree die-off has little effect on streamflow in contrast to expected increases from historical studies. Water Resources Research 51. DOI:10.1002/2015WR017401.

Bosch JM, Hewlett JD. 1982. A review of catchment experiments to determine the effect of vegetation changes on water yield and evapotranspiration. Journal of Hydrology 55: 3-23.

Brooks PD, Vivoni ER. 2008. Mountain ecohydrology: quantifying the role of vegetation in the water balance of montane catchments. Ecohydrology 1: 187-192.

Brown AE, Zhang L, McMahon TA, Western AW, Vertessy RA. 2005. A review of paired catchment studies for determining changes in water yield resulting from alterations in vegetation. Journal of Hydrology $\mathbf{3 1 0}$ : 28-61.

Burt TP, Howden NJK, McDonnell JJ, Jones JA, Hancock GR. 2015. Seeing the climate through the trees: observing climate and forestry impacts on streamflow using a 60-year record. Hydrological Processes 29: 473-480.

Chauvin G, Flerchinger GN, Link T, Marks D, Winstral AH, Seyfried MS 2011. Long-term water balance and conceptual model of a semi-arid mountainous catchment. Journal of Hydrology 400: 133-143.

Clark PE, Seyfried MS. 2001. Point sampling for leaf area index in sagebrush-steppe communities. Journal of Range Management 54: 589-594.

Cooley KR. 1988. Snowpack variability on western rangeland, pp 1-12 In: Proceeding of the Western Snow Conference, 56th Annual Meeting, April 19-21, Kalispell, MT. Colorado State University, Fort Collins, CO.

Deng Y, Flerchinger GN, Cooley KR. 1994. Impacts of spatially and temporally varying snowmelt on subsurface flow in a mountainous watershed: 2. Subsurface processes. Hydrological Sciences Journal 39: 521-533.

Flerchinger GN, Clark PE. 2003. Potential hydrologic response to a prescribed fire on a small mountainous watershed. p. 631-636 In: First Interagency Conference on Research in the Watersheds, Benson, AZ, October 27-30, 2003. USDA Agricultural Research Service, Southwest Watershed Research Center, Tucson, AZ

Flerchinger GN, Cooley KR. 2000. A ten-year water balance of a mountainous semi-arid watershed. Journal of Hydrology 237: 86-99.

Flerchinger GN, Cooley KR, Deng Y. 1994. Impacts of spatially and temporally varying snowmelt on subsurface flow in a mountainous watershed: 1. Snowmelt simulation. Hydrological Sciences Journal 39 (507): 520.

Flerchinger GN, Cooley KR, Hanson CL, Seyfried MS. 1998. A uniform versus an aggregated water balance of a semi-arid watershed. Hydrological Processes 12: 331-342.

Flerchinger GN, Cooley KR, Ralston DR. 1992. Groundwater response to snowmelt in a mountainous watershed. Journal of Hydrology 133: 293-311.

Flerchinger GN, Deng Y, Cooley KR. 1993. Groundwater response to snowmelt in a mountainous watershed: testing of conceptual model. Journal of Hydrology 152: 201-214.

Flerchinger GN, Hanson CL, Wight JR. 1996. Modeling evapotranspiration and surface energy budgets across a watershed. Water Resources Research 32(8): 2539-2548.
Flerchinger GN, Reba ML, Marks D. 2012. Measurement of surface energy fluxes from two rangeland sites and comparison with a multilayer canopy model. Journal of Hydrometeorology 13(3): $1038-1051$.

Flerchinger GN, Seyfried MS. 2014. Comparison of methods for estimating evapotranspiration in a small rangeland catchment. Vadose Zone Journal 13(4): 11. DOI:10.2136/vzj2013.08.0152.

Flerchinger GN, Xaio W, Marks D, Sauer TJ, Yu Q. 2009a. Comparison of algorithms for incoming atmospheric long-wave radiation. Water Resources Research 45: W03423. DOI:10.1029/2008WR007394.

Flerchinger GN, Xaio W, Sauer TJ, Yu Q. 2009b. Simulation of within canopy radiation exchange. Wageningen Journal of Life Scienes 57: 5-15.

Flerchinger GN, Yu Q. 2007. Simplified expressions for radiation scattering in canopies with ellipsoidal leaf angle distributions. Agricultural and Forest Meteorology 144: 230-235.

Guardiola-Claramonte M, Troch PA, Breshears DD, Huxman TE, Switanek MB, Durcik M, Cobb NS. 2011. Decreased streamflow in semi-arid basins following drought-induced tree die-off: a counterintuitive and indirect climate impact on hydrology. Journal of Hydrology 406: 225-233.

Harpold AA, Biederman JA, Condon K, Merino M, Korgaonkar Y, Nan T, Sloat LL, Ross M, Brooks PD. 2014. Changes in snow accumulation and ablation following the Las Conchas Forest Fire, New Mexico, USA. Ecohydrology 7: 440-452.

Huang Y, Wilcox BP, Stern L, Perotto-Baldivieso H. 2006. Springs on rangelands: runoff dynamics and influence of woody plant cover. Hydrological Processes 20: 3277-3288.

Huxman TE, Wilcox BP, Breshears DD, Scott RL, Snyder KA, Small EE, Hultine K, Pockman WT, Jackson RB. 2005. Ecohydrological implications of woody plant encroachment. Ecology 86(2): 308-319.

Kaimal, JC, and JJ Finnigan. 1994. Atmospheric Boundary Layer Flows Their Structure and Measurement, 289 pp., Oxford University Press, New York, NY.

Keppeler ET, Ziemer RR. 1990. Logging effects on streamflow: water yield and summer low flows at Caspar Creek in northwest California. Water Resources Research 26(7): 1669-1679.

Luce CH, Tarboton DG, Cooley KR. 1998. The influence of the spatial distribution of snow on basin-averaged snowmelt. Hydrological Processes 12(10-11): 1671-1684.

Marks D. 2001. Introduction to special section: Reynolds Creek Experimental Watershed. Water Resources Research 37(11): 2817.

Mock NA. 1988. A hydrological characterization of a zero-order basin in volcanic hillslope terrain, Master's Thesis, Civil and Environmental Engineering Department, Utah State University, Logan, Utah. 171 pp.

Miller RF, Bates JD, Svejcar TJ, Pierson FB, Eddleman LE. 2005. Biology, Ecology and Management of Western Juniper. Oregon State University Agricultural Experiment Station Technical Bulletin 152. 82 pp.

Miller RF, Rose JA. 1999. Fire history and western juniper encroachment in sagebrush steppe. Journal of Range Management 52: 550-559.

Moore RD, Wondzell SM. 2005. Physical hydrology and the effects of forest harvesting in the Pacific Northwest: a review. Journal of the American Water Resources Association 41(4): 763-784.

Ryan KC, Knapp EE, Varner JM. 2013. Prescribed fire in North American forests and woodlands: history, current practice, and challenges. Frontiers in Ecology and the Environment 11: e15-e24. DOI:10.1890/120329.

Schotanus P, Nieuwstadt FTM, De Bruin HAR. 1983. Temperature measurement with sonic anemometer and its application to heat and moisture fluxes. Boundary-Layer Meteorology 26: 81-93.

Seyfried MS, Murdock MD, Hanson CL, Flerchinger GN, Van Vactor S. 2001. Long-term soil water content database, Reynolds Creek Experimental Watershed, Idaho, United States. Water Resources Research 37: 2847-2851.

Seyfried MS, Wilcox BP. 2006. Soil water storage and rooting depth: key factors controlling recharge on rangelands. Hydrological Processes 20: 3261-3275.

Slaughter CW, Marks D, Flerchinger GN, VanVactor SS, Burgess M. 2001. Thirty-five years of research data collection at the Reynolds Creek Experimental Watershed, Idaho, United States. Water Resources Research 37(11): 2819-2823.

Stednick JD. 1996. Monitoring the effects of timber harvest on annual water yield. Journal of Hydrology 176: 79-95. 
Stevens GR. 1991. A Geophysical Investigation of the Upper Sheep Drainage, Reynolds Creek Experimental Watershed, Owyhee County, Idaho, Master's Thesis, Geophysics Program, University of Idaho, Moscow, Idaho, $119 \mathrm{pp}$.

Twidwell D, Rogers WE, Fuhlendorf SD, Wonkka CL, Engle DM, Weir JR, Kreuter UP, Taylor CA Jr. 2013. The rising Great Plains fire campaign: citizens' response to woody plant encroachment. Frontiers in Ecology and the Environment 11: e15-e24. DOI:10.1890/120329.

Twine TE, Kustas WP, Norman JM, Cook DR, Houser PR, Meyers TP, Prueger JH, Starks PJ, Wesely ML. 2000. Correcting eddy-covariance flux underestimates over a grassland. Agricultural and Forest Meteorology 103: 279-300.

Unnikrishna PV, McDonnell JJ Tarboton DG Kendall C, Flerchinger GN. 1995. Stable isotope tracing as a tool for testing assumptions in a grid based distributed hydrologic model. p.85 90 In: AMS Conference on Hydrology. January 15-20, 1995, Dallas TX. American Meteorological Society, Boston, MA.

Veatch W, Brooks PD, Gustafson JR, Molotch NP. 2009. Quantifying the effects of forest canopy cover on net snow accumulation at a continental, mid-latitude site. Ecohydrology 2: 115-128.

Webb EK, Pearman GI, Leuning R. 1980. Correction of flux measurements for density effects due to heat and water vapor transfer. Quarterly Journal of the Royal Meteorological Society 106: 85-100.
Wilcox BP. 2002. Shrub control and streamflow on rangelands: a process based viewpoint. Journal of Range Management 55(4): 318-326.

Wilcox BP, Huang Y, Walker JW. 2008. Long-term trends in streamflow from semiarid rangelands: uncovering drivers of change. Global Change Biology 14: 1676-1689.

Wilcox BP, Owens MK, Knight RW, Lyons RK. 2005. Do woody plants affect streamflow on semiarid karst rangelands? Ecological Applications 15: 127-136.

Wilcox BP, Thurow TL. 2006. Emerging issues in rangeland ecohydrology: vegetation change and the water cycle. Rangeland Ecology \& Management 59: 220-224.

Winkelmaier JR. 1987. Ground-water flow characteristics in fractured basalt in a zero-order basin, Master's Thesis, Hydrology Department, University of Idaho, Moscow. $128 \mathrm{pp}$.

Zhang M, Wei X, Sun P, Liu S. 2012. The effect of forest harvesting and climatic variability on runoff in a large watershed: the case study in the Upper Minjiang River of Yangtze River basin. Journal of Hydrology 464-465: $1-11$.

Zhao F, Zhang L, Xu Z, Scott DF. 2010. Evaluation of methods for estimating the effects of vegetation change and climate variability on streamflow. Water Resources Research 46: W03505. DOI:10.1029/ 2009WR007702. 